\title{
多変量解析による地下水水質の分類特性 一島原市における事例一
}

\author{
天野 弘基 1 -中川 啓 2 河村 明 $^{3}$ \\ 1 学生会員 長崎大学大学院水産・環境科学総合研究科（T852-8521 長崎市文教町 1-14） \\ 2 正会員 博 (工） 長崎大学教授 大学院水産・環境科学総合研究科（广852-8521 長崎市文教町 1-14） \\ E-mail: kei-naka@nagasaki-u.ac.jp \\ 3正会員 工博 首都大学東京教授 大学院都市環境科学研究科（ $\bar{\top} 192-0397$ 東京都八王子南大沢 1-1）
}

\begin{abstract}
島原市の地下水水質を対象として, 4 種類の多変量解析手法を適用し, どの分類結果が当該地域の水質特 性を説明するために適しているかについて検討した．5つのクラスターに分類した場合のそれぞれ特徴は, ほぼ同様であったが，各クラスターの空間分布については手法間に違いが認められ，主成分分析を利用し た手法は，硝酸性窒素濃度が比較的高い採水地点を，污染クラスターに分類した．クラスター数を 10 とし た場合に扔いても主成分分析を利用した手法がより適切な結果を与えうることが明らかとなった。
\end{abstract}

Key Words: water quality, nitrate pollution, principal component analysis, self-organizing map, hierarchical cluster analysis

\section{1. はじめに}

地下水水質の特徵を把握し, 分類するためトリリ ニアダイアグラムやへキサダイアグラムが用いられ ることが多い1 ${ }^{1,2)}$ 。一方, 多変量解析手法である主 成分分析を適用すると，陽イオン交換反応，蒸発，塩 水侵入, 硝酸性窒素污染や風化といった地下水組成 に影響を与える因子を抽出することができる。ここ で得られる主成分得点により, 抽出した因子の空間 的拡がりの特徵を把握することも可能である ${ }^{3), 4)}$. さらに, クラスター分析と組み合わせることにより, 水質特性の分類を効果的に行うことができ，多くの 事例が報告されている5 ${ }^{5)}$ ， たとえば沖縄本島南部 地域の事例では，主成分分析により海水や海塩の影 響, 施肥や生活排水の影響, 石灰岩の溶解, 酸化還元 状態等の因子を抽出し, さらにクラスター分析によ り調査地域の地下水水質を 4 つのクラスターに分類 し，それぞれの影響因子を評価した ${ }^{6)}$ 。また，ナイ ジェリア南東部エヌグの事例では, 主成分分析を行 い，母岩鉱物の風化と人為的活動の影響の因子を抽 出した。ささらに，クラスター分析により地下水水質 を污染負荷レベルの異なるグループに分類した ${ }^{8)}$.

最近, 主成分分析やクラスター分析に加え, 自己 組織化マップ（Self-organizing map，以下 SOM とす
る）を利用した水質特性のパターン分類が報告され るようになってきた ${ }^{9), 10)}$. SOM では多次元デー夕 の関連性を 2 次元マップ上で表現することができ, たとえばベトナム紅河デルタの事例では, 地下水中 の $\mathrm{Mg}^{2+}, \mathrm{Na}^{+}, \mathrm{K}^{+}$そて $\mathrm{Cl}^{-}$が $\mathrm{SOM}$ 上で類似したパ ターンを示したことから，これらのイオンの関連性 が明らかとなった 。 ささらに, クラスター分析を適 用し, 塩分濃度により特徵付けられる8つのクラス ターに地下水水質を分類した。

以上のように, 地下水水質特性を分類するために, いくつかの多変量解析手法を組み合わせて利用され てきたが，どのような組み合わせ方が研究対象地の 水質特性をより適切に説明できるかどうかの議論は 行われていない，そこで，本研究では長崎県島原市 の地下水水質デー夕を分析対象とし，（i 階層的ク ラスター分析のみによる分類，（ii）主成分分析と階 層的クラスター分析による分類, (iii) SOM と階層 的クラスター分析による分類，（iv）主成分分析およ びSOM と階層的クラスター分析による分類の 4 種 類の多変量解析手法を適用し, 分類結果を比較する ことにより，それぞれの分類特性とどの手法が島原 市の地下水水質特性を説明する上で適しているかに ついて検討した。 


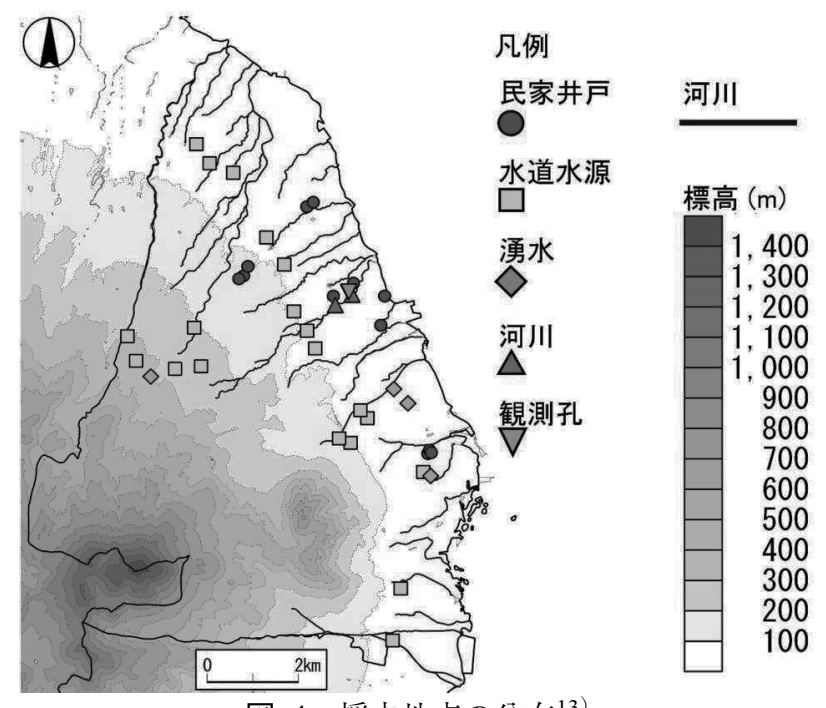

図-1 採水地点の分布 ${ }^{13)}$

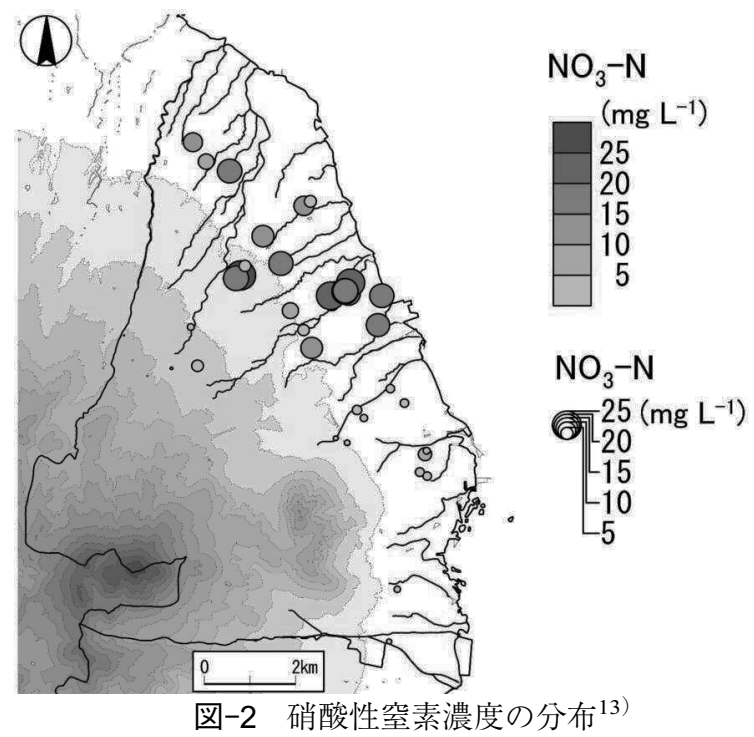

\section{2. 研究対象地の概要 ${ }^{11)}$}

研究対象地とした島原市は島原半島の北東部に位 置し，その $18 \%$ を占める面積は $82.8 \mathrm{~km}^{2}$ である。地 形は半島中心にそびえる普賢岳より東の有明海にか けてなだらかな斜面が広がる扇状地である。標高 300 1500 m に森林が広がり, 島原市北部の山の中腹 では畜産施設や集落が点在し始める。標高が低くな るにつれ，農地があたり一面を占め，道路沿いに民 家が建ち並ぶ。市北部の標高 $10 \mathrm{~m}$ 以下では海岸線 近くに民家が建ち並び，南部の標高 $50 \mathrm{~m}$ 以下では市 街地や商業施設が発達する。農業地帯は島原市の北 部に集中し, 島原市全体の $22.7 \%$ を占める。農作物 の白菜, 人参, 大根, すいか, ほうれんそうは長崎県 内シェアの 4 分の 1 以上を占める。島原市ではこれ らの作物を中心に二毛作により四季を問わず，年間 を通して農作物が栽培されている。一方，畜産にお
いては乳用牛 1,552 頭, 肉用牛 3,641 頭, 豚 54,820 頭, 採卵鶏 1,346 千羽, 肉用鶏 92 千羽が飼育されて おり $(2009$ 年), 長崎県内シェア率は, 採卵鵎の 65.4 $\%$ が最も高く, 次いで豚の $23.3 \%$ が高い. 以上のよ うに県内有数の農畜産施設であることがわかる。 1977 年から 2013 年に打ける年平均降水量は 2105 $\mathrm{mm}$, 年平均気温は $17.3{ }^{\circ} \mathrm{C}$ であった ${ }^{12)}$.

\section{3. 硝酸性窒素污染と地下水水質 ${ }^{13)}$}

研究対象地に抢ける 2011 年 8 月から 2013 年 11 月に実施した地下水水質調査では, 40 地点中（図-1） 15 地点で硝酸性窒素濃度が, 硝酸性窒素及び亜硝酸 性窒素の水道水質基準 ${ }^{14)}$ および環境基準 ${ }^{15)}$ である $10 \mathrm{mg} \mathrm{L}^{-1}$ を超過し, 40 地点中の 21 地点では, 人為的 活動の影響を受けているとされる闇值 ${ }^{16)} 3 \mathrm{mg} \mathrm{L}^{-1}$ を 超過していた（図-2). 高い硝酸性窒素濃度（>10 $\left.\mathrm{mg} \mathrm{L}^{-1}\right)$ は, 主に島原市北部の標高 $200 \mathrm{~m}$ 未満で観測 されて抢り, 硝酸性窒素濃度の空間分布と土地利用 を比較すると, 高い硝酸性窒素濃度は農業地域の空 間分布とよく一致した。市北部の標高 $200 \mathrm{~m}$ 以上に 分布する森林部や, 市南部の標高 $100 \mathrm{~m}$ 以下に発達 する市街地および郊外の採水地点における硝酸性窒 素濃度は, 基準值を満たすことから, 研究対象地で は硝酸性窒素污染と農業活動が密接に関係している ことが示唆された。

水質組成については, 硝酸性窒素が基準值を超過 するような採水地点は $\mathrm{Ca}^{-}\left(\mathrm{SO}_{4}+\mathrm{NO}_{3}\right)$ 型に分類さ れ，そうでない地点は $\mathrm{Ca}-\mathrm{HCO}_{3}$ 型に分類された（図 -3). 標高 300 400 $\mathrm{m}$ に位置する採水地点の溶存イ オン濃度は, 低い值を示し, 標高が低くなるにつれ 溶存イオン濃度は上昇する傾向が認められ, 黒雲母 や角閃石, 斜長石, かんらん石の溶解が, $\mathrm{K}^{+}$や $\mathrm{Mg}^{2+}$, $\mathrm{Ca}^{2+}$ 濃度の増加に寄与している可能性が示唆され た.

\section{4. 多変量解析}

\section{（1）解析方法}

本研究では，階層的クラスター分析のみによる分 類, 主成分分析と階層的クラスター分析による分類, SOM と階層的クラスター分析による分類, 主成分分 析およびSOM と階層的クラスター分析による分類 の 4 種類の多変量解析手法の比較, 検討を実施した. 検討対象としたのは, 2011 年 8 月から 2013 年 11 月 に 40 地点（図-1）で集めた 277 サンプルのイオン濃 


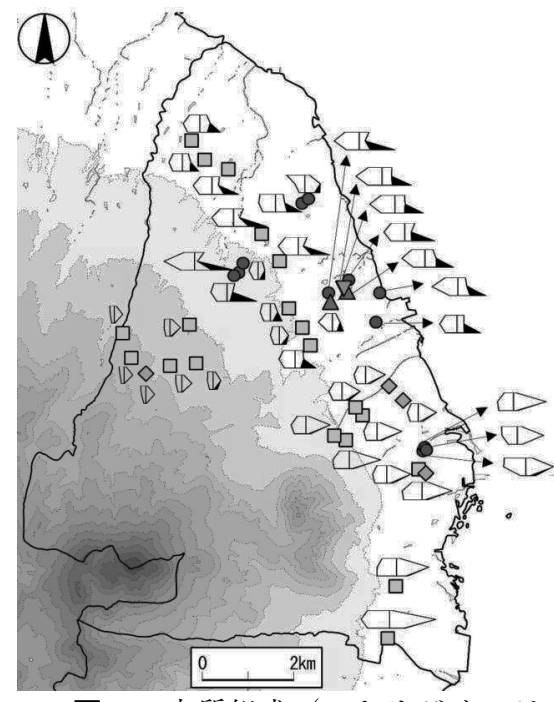

図-3 水質組成 (ヘキサダイアグラム) の分布 ${ }^{13)}$

度デー夕 $\left(\mathrm{Cl}^{-}, \mathrm{NO}_{3}{ }^{-}, \mathrm{SO}_{4}{ }^{2-}, \mathrm{HCO}_{3}{ }^{-}, \mathrm{Na}^{+}, \mathrm{K}^{+}, \mathrm{Mg}^{2+}\right.$, $\left.\mathrm{Ca}^{2+}\right)$ である ${ }^{13)}$ ，民家井戸と水道水源では深井戸お よび浅井戸で，およそ2ヶ月の間隔でサンプリング を実施している（深井戸と浅井戸は深度 $30 \mathrm{~m}$ で分類 されている)，硝酸性窒素濃度は，降雨時の希䣋など による解析期間中の変動がみられる ${ }^{13)}$ 。階層的クラ スター分析にはW Ward 法を採用した。 クラスター数 は，DBI（Davies-Bouldin Index） ${ }^{17)} に$ 基づき決定し た. クラスター数を 2 から入力データ総数まで変化 させ，DBI 值を算出し，最小となる場合が最適クラ スター数である。 DBI 值は元のデー夕を用いた場 合, 主成分分析の後に求める場合, SOM 解析を行っ た後に求める場合で異なるが, 本研究では, 4 種類の 手法間の比較検討を行うため, 後の手法 3 , すなわち 主要溶存イオン 8 成分の濃度に基づき SOM 解析の 後に決定された最適クラスター数 5 を共通して採用 した。さらに，クラスター数を多く設定し，詳細に 分類する場合の特性比較のため, 2 番目の最適クラ スター数 10 とした場合も検討に加えた４ 種類の手 法による分析結果は, 各クラスターの特徵を把握す るため, クラスターごとに主要溶存イオン濃度の平 均を算出し, クラスターの研究対象地上の空間分布 を描画し, 硝酸性窒素濃度掞よび水質組成の分布と 対比しながら手法ごとに検討を加えた。

\section{a）階層的クラスター分析 ${ }^{13)}$}

主要溶存イオン 8 成分の濃度 $(8$ 次元 277 ベクト ル）を入力データとして階層的クラスター分析 （HCA）のみを実行し, 分類した. 以降, 「手法 $1 」$ と する.

\section{b）主成分分析と階層的クラスター分析}

まず，主要溶存イオン 8 成分の濃度に基づき主成 分分析（PCA）を実行し，主成分分析より得られた第
1 , 第 2 主成分得点 (2 次元 277 ベクトル) を入力デー 夕としてHCA を実行し, 分類した。 以降，「手法 2」 とする.なお, PCA は相関係数行列を用いて実行し, 第 1 ，第 2 主成分の寄与率はそれぞれ $59.7 \%, 26.8$ $\%$ で，累積寄与率は $86.5 \%$ となる。

c) SOM と階層的クラスター分析 ${ }^{18)}$

初めに, 主要溶存イオン 8 成分の濃度に基づき SOM を作成した後, 得られた 84 の参照ベクトル（8 次元 84 ベクトル）を入力データとして HCA を実行 し，分類した，以降，「手法 $3 」$ とする。

d）主成分分析およびSOM と階層的クラスター分析 手法 2 と同様に, まず主要溶存イオン 8 成分の濃 度に基づき主成分分析を実行し, 第 1 , 第 2 主成分得 点 (2 次元 277 ベクトル) を得た。次に主成分分析で 得た第 1 , 第 2 主成分得点 (2 次元 277 ベクトル) に 基づき SOMを作成した。最後に，SOMで得られた 81 の参照ベクトル (2 次元 81 ベクトル) を入力デー 夕として HCA を実行し, 分類した。 以降,「手法4」 とする。

\section{（2）自己組織化マップ（SOM）}

SOM は, Kohonen ${ }^{19)} に よ り$ 開発されたニューラル ネットワーク手法の一種で, 教師なしで多次元デー 夕の関連性を 2 次元に写像する。この機能により, 多次元データから抽出したパターンを 2 次元マップ 上に視覚化し比較することができる，著者らによる 同じ研究対象地における 2012 年 4 月から 2015 年 8 月の水質デー夕に SOM を適用した事例では, $\mathrm{Cl}^{-}$と $\mathrm{NO}_{3}{ }^{-}, \mathrm{Na}^{+}$と $\mathrm{Mg}^{2+}$ の $\mathrm{SOM}$ が類似したパターンを示 し, これらのイオンの相関の高さが視覚的に判断で きた ${ }^{18)}$. SOM は, ニューロンまたはノードと呼ばれ る六角格子が規則正しく配列することで構成され る。 入力データの特徵を適切に抽出するために, 経 験則 $M=5 \sqrt{n}$ ( $M:$ ニューロン数, $n$ :入力デー夕数 $)$ により総ニューロン数は決定され，また縦と横の ニューロン数の比は，入力データの共分散行列にお ける固有值ベクトルの第 1 および第 2 成分の比率よ り決定される17),20)。本研究では, これらの経験則 に従い, 手法 3 では縦 $12 \times$ 横 7 の総ニューロン数 84, 手法 4 では縦 $9 \times$ 横 9 の総ニューロン数 81 の SOM をそれぞれ構築した（図-4，5）。SOM 構築後, 入力データと同次元の参照ベクトル（手法 3 では 8 次元, 手法 4 では 2 次元）が各ニューロンに配置さ れ，これらの参照ベクトルは入力データの特徵を反 映するように，学習プロセスを通して繰り返し更新 される. 結果として, 近接するニューロンは互いに 類似した特徵を持ち，遠隔のニューロンはそれぞれ 


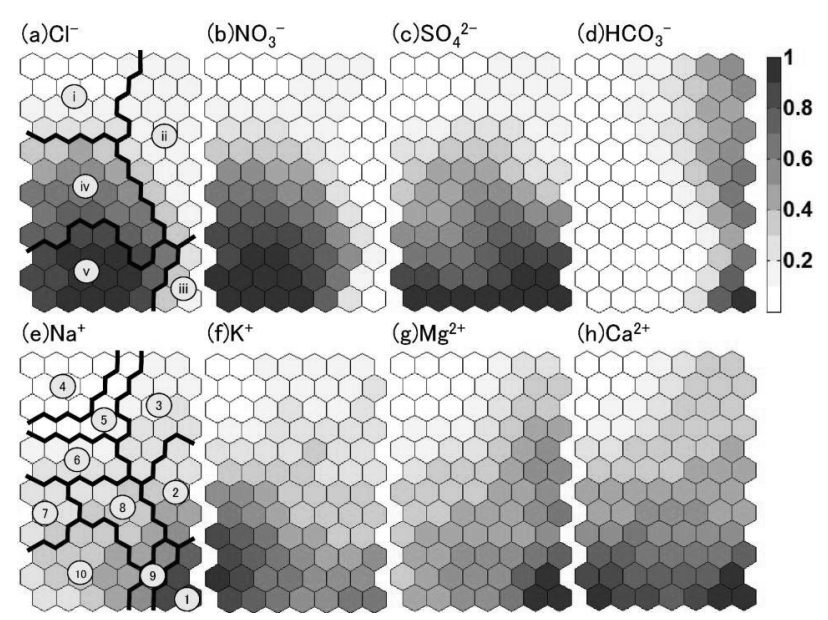

図-4 手法 3 により作成した主要溶存イオン 8 成分の SOM

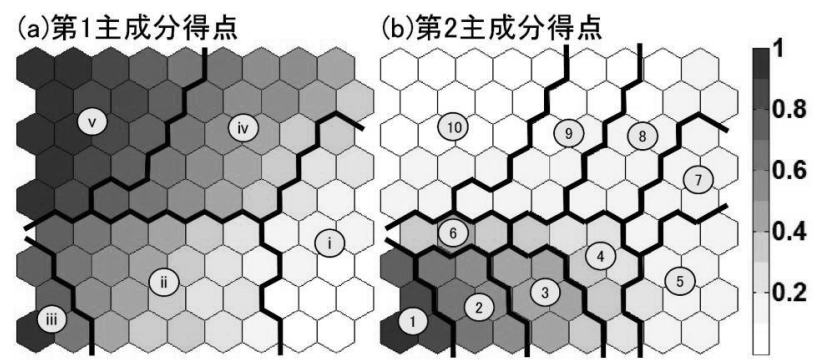

図-5 手法 4 により作成した主成分得点の SOM

異なる特徵を示す。最終的に，入力データは，性質 が最も類似した（ユークリッド距離が最短）ニュー ロンに分類される.

図-4に手法 3 により作成したSOMを示す。黑の 実線はクラスターの数を 5 とした場合とクラスター の数を 10 とした場合のクラスター境界を表し, SOM 上のそれぞれの数字はクラスターの番号を表 す. Nakagawa et al. ${ }^{18)}$ が報告した結果と同様に, $\mathrm{Cl}^{-}$ と $\mathrm{NO}_{3}{ }^{-}, \mathrm{Na}^{+}$と $\mathrm{Mg}^{2+}$ の $\mathrm{SOM}$ のパターンが類似して おり，これらのイオンの相関の高さが窺える。図-5 に手法 4 によるSOM を示す. Nakagawa et al. ${ }^{13)}$ によ ると, 第 1 主成分はイオンの溶解と硝酸性窒素污染, 第 2 主成分はイオンの溶解を表しているため, 両者 のSOM のパターンは明確に異なる。あとの分類結 果については, クラスターの数を5（クラスターi〜 v）とした場合とクラスターの数を 10（クラスター 1 10）とした場合，それぞれで検討しているが, 両者 の対応関係は以下のようである。手法 3 では, クラ スター 4 と 5 がクラスター iである。 クラスター 2 と 3 がクラスター ii , クラスター 1 がクラスター iii, クラスター 6, 7 拈よび 8 がクラスターiv, そしてク ラスター 9 と 10 がクラスターvである. 手法 4 で は, クラスター 5 と 7 がクラスター i, クラスター 2，3，4 および6がクラスター ii , クラスター 1 がク ラスター iii, クラスター 8 と 9 がクラスター iv, ク
ラスター 10 がクラスター $\mathrm{v}$ に対応する.

\section{4 つの多変量解析手法による水質特性の分類}

ここでは, クラスターの数を 5 とした場合とクラ スターの数を 10 とした場合のそれぞれの解析結果 の違いについて議論する。

\section{（1）クラスターの数を 5 とした場合}

表-1に，各クラスターに打硅要溶存イオンと 硝酸性窒素 $\left(\mathrm{NO}_{3}-\mathrm{N}\right)$ の平均濃度をそれぞれの解析 手法ごとに示す。いずれの手法においても5つのク ラスターは, 硝酸性窒素濃度が人為的活動の影響を 受けているとされる䦨值 ${ }^{16)} 3 \mathrm{mg} \mathrm{L}^{-1}$ を超えないクラ スター i , ii , iii (以下, 污染の影響を受けていない クラスターとする) と平均の硝酸性窒素濃度が硝酸 性窒素及び亜硝酸性窒素の水道水質基準 ${ }^{14)}$ および環 境基準 ${ }^{15)} 10 \mathrm{mg} \mathrm{L}^{-1}$ を超過するクラスター iv, v (以 下，污染クラスターとする）に分けることができる. なお，HCAによるクラスター分類は，デンドログラ ムによると, 手法 3 のみ i, ii と iii, iv, vに大別さ れたが，それ以外の手法ではi，ii， iii とiv，vに大 別された。污染の影響を受けていない 3 つのクラス ターを比較すると, $\mathrm{NO}_{3}{ }^{-}$を除き, 各種イオン濃度に 違いが認められる。いずれの手法においてもクラス ター iiiが最も溶存イオン濃度が高く, ついでクラス ター ii , そしてクラスター i が低い. 2つの污染ク ラスターも同様に，污染レベルで区別できる，クラ スターivの硝酸性窒素濃度は 11.4 13.4 $\mathrm{mg} \mathrm{L}^{-1}$ であ り，水道水質基準 ${ }^{14)}$ および環境基準 ${ }^{15)}$ よりわずかに 高い值を示しているが, クラスター $\mathrm{v}$ の硝酸性窒素 濃度はクラスター iv の 1.5 倍より大きい值 (19.2 20.5 $\left.\mathrm{mg} \mathrm{L}^{-1}\right)$ を示した.

図-6に各クラスターの分布を解析手法ごとに示 す。なお，各地点とも観測期間最新の分析值による クラスターをプロットした。 クラスター $\mathrm{i}$ の分布に 着目すると, A, B, C 点（図-6）を除き, 全ての解析 手法に扔いて同じ分布を示した。 $\mathrm{A}$ 点は, 手法 1 と 3 では, クラスター i に分類され（図-6 (a)，(c)), $\mathrm{B}, \mathrm{C}$ 点は, 手法 3 でのみ, クラスター $\mathrm{i}$ に分類され た (図-6 (c) ). クラスター ii は, 市南部の標高 100 $\mathrm{m}$ 以下に分布しており, B， C 点を除き, 全ての解析 手法で同じ分布を示した。 クラスター iii に分類され た採水地点は, 全ての解析手法において市の最南部 に位置する地点のみである。クラスターivと $\mathrm{v}$ は市 の北部に分布しており, 解析手法により分布が異な る。しかし, どちらのクラスターも硝酸性窒素濃度 
表-1 クラスターの数を 5 とした場合の各クラスターに おける主要溶存イオンと硝酸性窒素 $\left(\mathrm{NO}_{3}-\mathrm{N}\right)$ の平 均濃度

\begin{tabular}{|c|c|c|c|c|c|c|c|c|c|c|}
\hline & クラスター & $\begin{array}{c}\mathrm{Cl}^{-} \\
\mathrm{mg} \mathrm{L}^{-1}\end{array}$ & $\begin{array}{l}\mathrm{NO}_{3}^{-} \\
\mathrm{mg} \mathrm{L}^{-1}\end{array}$ & $\begin{array}{l}\mathrm{SO}_{4}^{2-} \\
\mathrm{mg} \mathrm{L}^{-1}\end{array}$ & $\begin{array}{l}\mathrm{HCO}_{3}^{-} \\
\mathrm{mg} \mathrm{L}^{-1}\end{array}$ & $\begin{array}{c}\mathrm{Na}^{+} \\
\mathrm{mg} \mathrm{L}^{-1}\end{array}$ & $\begin{array}{c}\mathrm{K}^{+} \\
\mathrm{mg} \mathrm{L}^{-1}\end{array}$ & $\begin{array}{c}\mathrm{Mg}^{2+} \\
\mathrm{mg} \mathrm{L}^{-1}\end{array}$ & $\begin{array}{c}\mathrm{Ca}^{2+} \\
\mathrm{mg} \mathrm{L}^{-1}\end{array}$ & $\begin{array}{l}\mathrm{NO}_{3}-\mathrm{N} \\
\mathrm{mg} \mathrm{L}^{-1}\end{array}$ \\
\hline \multirow{5}{*}{ 手法1 } & $\mathrm{i}$ & 5.3 & 11.7 & 3.8 & 37.7 & 7.0 & 3.7 & 3.5 & 9.2 & 2.6 \\
\hline & ii & 6.7 & 9.9 & 13.6 & 113.0 & 13.2 & 5.3 & 10.9 & 21.0 & 2.2 \\
\hline & iii & 7.1 & 5.2 & 49.7 & 209.2 & 31.7 & 8.8 & 21.4 & 44.6 & 1.2 \\
\hline & iv & 16.4 & 56.3 & 25.0 & 36.2 & 12.9 & 6.9 & 9.1 & 21.8 & 12.7 \\
\hline & $v$ & 22.6 & 85.6 & 41.6 & 27.3 & 15.3 & 9.3 & 11.3 & 33.9 & 19.3 \\
\hline \multirow{5}{*}{ 手法2 } & i & 4.7 & 8.1 & 3.0 & 38.5 & 6.6 & 3.5 & 3.2 & 8.4 & 1.8 \\
\hline & ii & 6.7 & 9.9 & 13.5 & 112.1 & 13.2 & 5.2 & 10.8 & 20.9 & 2.2 \\
\hline & iii & 7.1 & 5.2 & 49.7 & 209.2 & 31.7 & 8.8 & 21.4 & 44.6 & 1.2 \\
\hline & iv & 14.8 & 50.5 & 22.5 & 35.7 & 12.4 & 6.2 & 8.3 & 20.2 & 11.4 \\
\hline & V & 22.4 & 85.1 & 40.1 & 27.5 & 15.1 & 9.3 & 11.2 & 33.2 & 19.2 \\
\hline \multirow{5}{*}{ 手法3 } & i & 4.9 & 9.0 & 3.5 & 39.3 & 6.7 & 3.6 & 3.3 & 8.7 & 2.0 \\
\hline & ii & 6.9 & 10.5 & 13.5 & 111.1 & 13.2 & 5.3 & 10.8 & 21.1 & 2.4 \\
\hline & iii & 7.1 & 5.2 & 49.7 & 209.2 & 31.7 & 8.8 & 21.4 & 44.6 & 1.2 \\
\hline & iv & 16.8 & 59.3 & 27.2 & 33.3 & 13.3 & 7.0 & 9.1 & 22.6 & 13.4 \\
\hline & $\mathrm{v}$ & 23.7 & 90.6 & 42.8 & 26.7 & 15.4 & 9.7 & 11.6 & 36.3 & 20.5 \\
\hline \multirow{5}{*}{ 手法4 } & 1 & 4.8 & 8.8 & 3.1 & 38.2 & 6.7 & 3.5 & 3.2 & 8.5 & 2.0 \\
\hline & ii & 6.7 & 10.0 & 13.2 & 111.4 & 13.1 & 5.2 & 10.7 & 20.9 & 2.3 \\
\hline & iii & 7.1 & 5.2 & 48.1 & 204.3 & 30.8 & 8.6 & 21.1 & 42.8 & 1.2 \\
\hline & iv & 15.4 & 53.2 & 23.4 & 35.6 & 12.5 & 6.4 & 8.5 & 20.8 & 12.0 \\
\hline & $\mathrm{v}$ & 22.6 & 85.7 & 40.9 & 27.2 & 15.3 & 9.5 & 11.3 & 33.8 & 19.4 \\
\hline
\end{tabular}

が基準值を超過している点で同じであり, クラス ター ivと vの分布の違いはさほど重要ではない．特 筆すべき点は，解析手法によってクラスター i にも ivにも分類される A 点についてである. クラスター ivと v の分類結果の違いは污染レベルの違いである が，クラスター i は污染の影響を受けていないクラ スターであり, クラスターivは污染クラスターであ るため, どちらに分類されるかで採水地点の水質特 性は大きく異なる。

次に, 手法 1 と 3 , 手法 2 と 4 のどちらが島原市の 水質を説明するに適しているか硝酸性窒素濃度の分 布とクラスターの分布を比較することで検討した. クラスター i もしくは ivに分類される A 点の硝酸性 窒素濃度は, $10 \mathrm{~m} \mathrm{~L}^{-1}$ (硝酸性窒素及び亜硝酸性窒 素の水道水質基準 ${ }^{14)}$ 抢よび環境基準 ${ }^{15)}$ ) を超えない ものの $3 \mathrm{mg} \mathrm{L}^{-1}$ (人為的活動の影響の閾值 ${ }^{16)}$ ) を超過 した，そのため, この採水地点は, 污染クラスター に分類するほうがより適切である。手法 1 と 3 そし
て手法 2 と 4 の大きな違いは, 主成分分析を実行し, パラメータを減らしたうえでクラスター分析したか どうかである. 以上のことから, 得られた主要溶存 イオン濃度を用いてクラスター分析, またはSOM を介してクラスター分析するよりも，主成分分析よ り得た主成分得点を利用してクラスター分析もしく はSOMを介してクラスター分析したほうが, 硝酸 性窒素濃度の污染レベルに対応したサンプリング地 点の分類ができることから，合理的な水質特性を表 現できたと考えられる.

図-7に各クラスターのヘキサダイアグラムを示 す。なお，それぞれの手法で各クラスターの特徵は ほぼ同様であったため, 手法間で各クラスターの各 種イオンの濃度を算術平均し、ヘキサダイアグラム を描画した，污染の影響を受けていないクラスター $\mathrm{i} \sim$ iii の水質組成は, 同じ $\mathrm{Ca}-\mathrm{HCO}_{3}$ 型を示すが, そ の溶存イオン濃度が異なることが, ヘキサダイアグ ラムから判読できる。一方, 污染クラスターである クラスター ivと $\mathrm{v}$ の水質組成は $\mathrm{Ca}-\mathrm{NO}_{3}$ 型を示す.

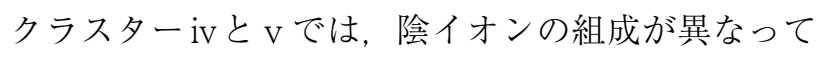
おり, ivでは $\mathrm{NO}_{3}{ }^{-}>\mathrm{HCO}_{3}{ }^{-}>\mathrm{SO}_{4}{ }^{2-}>\mathrm{Cl}^{-}$であり, $\mathrm{v}$ で は $\mathrm{NO}_{3}{ }^{-}>\mathrm{SO}_{4}{ }^{2-}>\mathrm{Cl}^{-}>\mathrm{HCO}_{3}{ }^{-}$である.

\section{（2）クラスターの数を 10 とした場合}

次にクラスターの数を 10 とした場合について検 討する. 表-2に各クラスターにおける主要溶存イオ ンと硝酸性窒素 $\left(\mathrm{NO}_{3}-\mathrm{N}\right)$ の平均濃度をそれぞれの 解析手法ごとに示す．クラスターの数を 5 とした場 合と異なり，10のクラスターは，大きく 3 つのクラ スターに分けることができる．1つはクラスターの 数を 5 とした場合と同様に, 污染の影響を受けてい
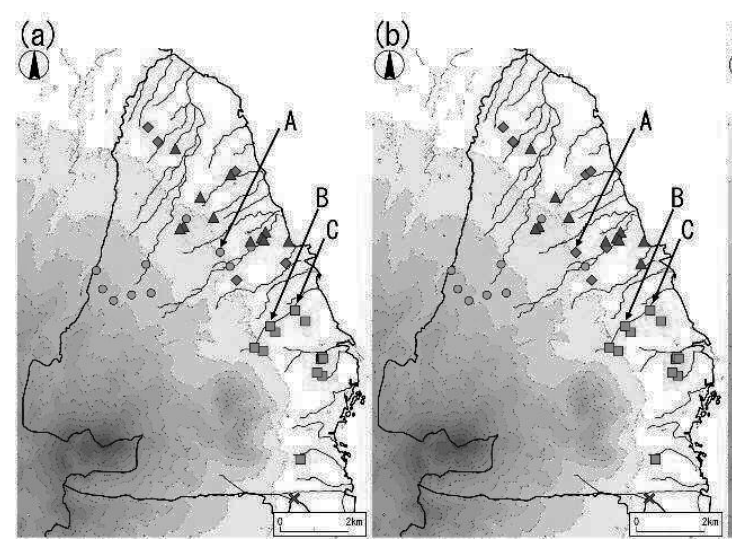

(c)
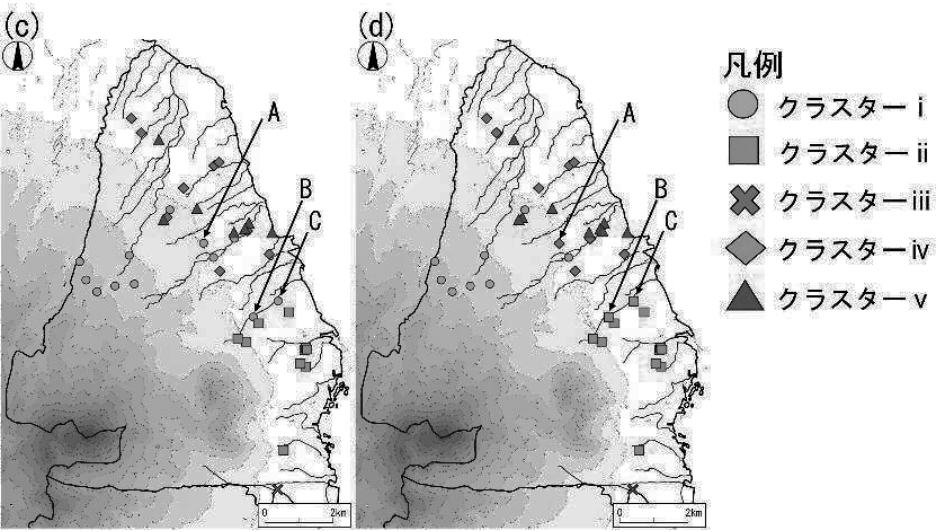

図-6 クラスターの数を 5 とした場合の各クラスターの分布； (a) 手法 1

\begin{abstract}
（b）手法 2, (c) 手法 3, (d) 手法 4
\end{abstract}

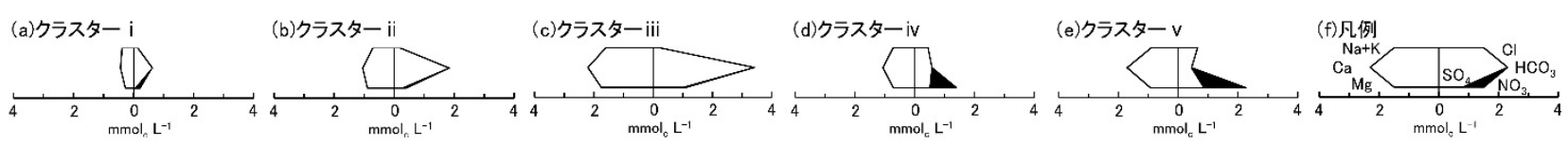

図-7 クラスターの数を 5 とした場合の各クラスターのヘキサダイアグラム 
表-2 クラスターの数を 10 とした場合の各クラスターに おける主要溶存イオンと硝酸性窒素 $\left(\mathrm{NO}_{3}-\mathrm{N}\right)$ の平 均濃度

\begin{tabular}{|c|c|c|c|c|c|c|c|c|c|c|}
\hline & クラスター & $\begin{array}{c}\mathrm{Cl}^{-} \\
\mathrm{mg} \mathrm{L}^{-1}\end{array}$ & $\begin{array}{l}\mathrm{NO}_{3}^{-} \\
\mathrm{mg} \mathrm{L}^{-1}\end{array}$ & $\begin{array}{l}\mathrm{SO}_{4}^{2-} \\
\mathrm{mg} \mathrm{L}^{-1}\end{array}$ & $\begin{array}{l}\mathrm{HCO}_{3}^{-} \\
\mathrm{mg} \mathrm{L}^{-1}\end{array}$ & $\begin{array}{c}\mathrm{Na}^{+} \\
\mathrm{mg} \mathrm{L}^{-1}\end{array}$ & $\begin{array}{c}\mathrm{K}^{+} \\
\mathrm{mg} \mathrm{L}^{-1}\end{array}$ & $\begin{array}{c}\mathrm{Mg}^{2+} \\
\mathrm{mg} \mathrm{L}^{-1}\end{array}$ & $\begin{array}{c}\mathrm{Ca}^{2+} \\
\mathrm{mg} \mathrm{L}^{-1}\end{array}$ & $\begin{array}{l}\mathrm{NO}_{3}-\mathrm{N} \\
\mathrm{mg} \mathrm{L}^{-1}\end{array}$ \\
\hline \multirow{10}{*}{ 手法1 } & 1 & 7.1 & 5.4 & 51.7 & 214.0 & 33.9 & 9.1 & 19.2 & 38.7 & 1.2 \\
\hline & 2 & 7.3 & 4.6 & 40.8 & 187.3 & 22.2 & 7.8 & 30.9 & 71.0 & 1.0 \\
\hline & 3 & 6.9 & 7.1 & 17.3 & 131.8 & 15.8 & 5.9 & 13.4 & 23.6 & 1.6 \\
\hline & 4 & 6.6 & 12.1 & 10.6 & 97.6 & 11.1 & 4.7 & 8.8 & 18.8 & 2.7 \\
\hline & 5 & 3.9 & 3.6 & 1.4 & 38.1 & 6.3 & 3.3 & 2.6 & 6.5 & 0.8 \\
\hline & 6 & 7.8 & 25.5 & 7.8 & 36.8 & 8.3 & 4.3 & 4.9 & 13.9 & 5.8 \\
\hline & 7 & 16.4 & 56.3 & 25.0 & 36.2 & 12.9 & 6.9 & 9.1 & 21.8 & 12.7 \\
\hline & 8 & 18.6 & 73.4 & 38.1 & 35.9 & 13.2 & 13.2 & 7.9 & 35.5 & 16.6 \\
\hline & 9 & 22.6 & 81.0 & 52.2 & 21.2 & 14.9 & 7.8 & 12.1 & 33.7 & 18.3 \\
\hline & 10 & 24.4 & 96.4 & 30.7 & 30.8 & 16.7 & 9.5 & 11.9 & 33.5 & 21.8 \\
\hline \multirow{10}{*}{ 手法2 } & 1 & 7.1 & 5.2 & 49.7 & 209.2 & 31.7 & 8.8 & 21.4 & 44.6 & 1.2 \\
\hline & 2 & 8.2 & 9.5 & 28.4 & 133.0 & 19.2 & 6.5 & 14.0 & 24.6 & 2.1 \\
\hline & 3 & 6.0 & 5.4 & 9.5 & 134.0 & 12.8 & 5.5 & 12.4 & 23.0 & 1.2 \\
\hline & 4 & 6.6 & 12.6 & 10.6 & 92.6 & 11.3 & 4.6 & 8.8 & 18.5 & 2.8 \\
\hline & 5 & 3.7 & 2.4 & 1.2 & 38.9 & 6.2 & 3.2 & 2.6 & 6.3 & 0.5 \\
\hline & 6 & 6.4 & 18.2 & 6.2 & 37.7 & 7.5 & 4.0 & 4.3 & 12.1 & 4.1 \\
\hline & 7 & 11.5 & 37.0 & 16.3 & 31.2 & 10.2 & 4.8 & 6.4 & 15.8 & 8.4 \\
\hline & 8 & 16.4 & 56.9 & 25.5 & 37.8 & 13.4 & 6.9 & 9.2 & 22.2 & 12.8 \\
\hline & 9 & 21.0 & 80.0 & 36.3 & 27.5 & 14.0 & 8.8 & 10.5 & 29.7 & 18.1 \\
\hline & 10 & 24.6 & 93.0 & 46.0 & 27.5 & 16.8 & 10.2 & 12.3 & 38.7 & 21.0 \\
\hline \multirow{10}{*}{ 手法3 } & 1 & 7.1 & 5.2 & 49.7 & 209.2 & 31.7 & 8.8 & 21.4 & 44.6 & 1.2 \\
\hline & 2 & 6.8 & 7.2 & 17.7 & 131.2 & 15.9 & 5.9 & 13.2 & 23.5 & 1.6 \\
\hline & 3 & 6.9 & 13.0 & 10.4 & 96.2 & 11.2 & 4.9 & 9.1 & 19.4 & 2.9 \\
\hline & 4 & 4.3 & 6.0 & 2.3 & 38.3 & 6.4 & 3.4 & 2.9 & 7.3 & 1.4 \\
\hline & 5 & 7.6 & 22.2 & 8.3 & 44.1 & 8.0 & 4.7 & 5.2 & 15.0 & 5.0 \\
\hline & 6 & 13.0 & 39.6 & 20.5 & 35.7 & 11.9 & 5.1 & 7.4 & 17.7 & 9.0 \\
\hline & 7 & 17.9 & 69.7 & 22.8 & 33.9 & 13.0 & 9.3 & 8.9 & 23.9 & 15.7 \\
\hline & 8 & 18.5 & 64.2 & 35.9 & 31.0 & 14.6 & 6.3 & 10.6 & 25.0 & 14.5 \\
\hline & 9 & 24.8 & 85.4 & 31.5 & 77.7 & 22.2 & 9.6 & 14.4 & 44.9 & 19.3 \\
\hline & 10 & 23.7 & 90.7 & 43.0 & 25.7 & 15.3 & 9.7 & 11.6 & 36.1 & 20.5 \\
\hline \multirow{10}{*}{ 手法4 } & 1 & 7.1 & 5.2 & 48.1 & 204.3 & 30.8 & 8.6 & 21.1 & 42.8 & 1.2 \\
\hline & 2 & 6.9 & 7.1 & 16.5 & 132.2 & 15.4 & 5.9 & 13.0 & 23.6 & 1.6 \\
\hline & 3 & 6.7 & 11.3 & 11.2 & 104.4 & 12.1 & 4.8 & 9.5 & 19.2 & 2.6 \\
\hline & 4 & 6.5 & 13.8 & 8.5 & & 9.0 & 4.6 & 6.9 & 17.2 & 3.1 \\
\hline & 5 & 4.3 & 6.1 & 2.4 & 38.2 & 6.4 & 3.4 & 2.9 & 7.3 & 1.4 \\
\hline & 6 & 10.3 & 21.4 & 32.2 & 64.8 & 23.3 & 10.3 & 4.8 & 14.0 & 4.8 \\
\hline & 7 & 8.8 & 30.8 & 8.3 & 34.0 & 9.0 & 4.8 & 5.2 & 14.7 & 6.9 \\
\hline & 8 & 14.2 & 40.2 & 25.1 & 36.5 & 11.4 & 5.2 & 7.9 & 19.6 & 9.1 \\
\hline & 9 & 17.2 & 63.3 & 25.4 & 35.2 & 13.4 & 7.0 & 9.6 & 22.6 & 14.3 \\
\hline & 10 & 22.5 & 85.4 & 40.8 & 27.1 & 15.2 & 9.4 & 11.3 & 33.6 & 19.3 \\
\hline
\end{tabular}

ないクラスターであり，クラスターの数を 5 とした 場合と同様に, $\mathrm{NO}_{3}{ }^{-}$を除き, 各種イオン濃度の違い で区別できる。手法 1 と 2 ではクラスター 1〜 , 手 法 3 ではクラスター1〜4, 手法 4 ではクラスター 1〜3と 5 がこのクラスターに属する. もう 1 つは, 同じくクラスターの数を 5 とした場合と同様に, 硝 酸性窒素及び亜硝酸性窒素の水道水質基準 ${ }^{14}$ および 環境基準 ${ }^{15)} 10 \mathrm{mg} \mathrm{L}^{-1}$ を超過する污染クラスターであ り, 手法 1 ではクラスター 7〜10, 手法 2 ではクラス ター8〜 10, 手法 3ではクラスター 7〜 10, そして手 法 4 ではクラスター9 210 がこのクラスターに属 する。どちらにも属さないクラスターが, 手法 1 で はクラスター 6, 手法 2 ではクラスター 6 と 7, 手法 3 ではクラスター 5 と 6 , 手法 4 ではクラスター 4 と 6〜8 がそれぞれの手法にあるが, 硝酸性窒素濃度に 着目すると, 人為的活動の影響の閾值 ${ }^{16)} 3 \mathrm{mg} \mathrm{L}^{-1}$ 超え ているものの, 硝酸性窒素及び亜硝酸性窒素の水道 水質基準 ${ }^{14)}$ および環境基準 ${ }^{15)} 10 \mathrm{mg} \mathrm{L}^{-1}$ を満たしてい

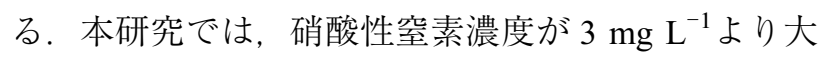
きく $10 \mathrm{mg} \mathrm{L}^{-1}$ 以下のクラスターを準污染クラスター と定義する。

図-8に各クラスターの分布を解析手法ごとに示 す。なお. 各地点とも観測期間最新の分析值による クラスターをプロットした. クラスターの数を 5 と した場合と異なり，各クラスターの持つ意味がそれ ぞれの手法で必ずしも一致しないので比較には注意 を要する。市の最南部に位置する採水地点のクラス
ターが, 他の採水地点のクラスターと異なることは, どの手法においても共通している。標高 $200 \mathrm{~m}$ 以上 に位置する採水地点に着目すると, 手法 3 では全て の地点が同じクラスターに分類されたが(図-8 (c)), 手法 1 と 2 では D 点（図-8（a)，(b)), 手法 4 では $\mathrm{G}$ 点（図-8 (d)) が異なるクラスターに分類された. 標高 $100 \mathrm{~m}$ 以下の市南部に着目すると, 手法 1 と 2 では，すべての採水地点が污染の影響を受けていな いクラスターに分類されたが, 手法 3 では B, C 点(図 -8 (c)), 手法 4 では B, C, E 点 (図-8 (d)) が準 污染クラスターに分類された。標高 $200 \mathrm{~m}$ 以下の市 北部に着目すると, 手法 1 と 2 では, すべての採水 地点が準污染もしくは污染クラスターに分類された が, 手法 3 と 4 では F 点（図-8（c)，(d)）のみ污染 の影響を受けていないクラスターに分類された.

クラスターの数を 5 とした場合と同様に, どの解 析手法による分類結果が島原市の水質を説明するう えで適しているか硝酸性窒素濃度の分布とクラス ターの分布を比較することで検討した。 まず手法 4 では， B, C, E, G 点が準污染クラスター（クラス ター4）に分類されているが，4地点の硝酸性窒素濃 度は $3 \mathrm{mg} \mathrm{L}^{-1}$ 以下であり，適切に分類できていない. 手法 3 では, 手法 4 と同様に B, C 点 (図-8 (c)) が 準污染クラスター(クラスター 5) に分類されており, 手法 3 による分類は適切ではない. 手法 1 と 2 で は, 污染クラスター, 準污染クラスター, 污染の影響 を受けていないクラスターの分布はほとんど一致し ている。手法 1 と 2 では, 硝酸性窒素濃度が $3 \mathrm{mg}$ $\mathrm{L}^{-1}$ より大きく $10 \mathrm{mg} \mathrm{L}^{-1}$ 以下の $\mathrm{D}, \mathrm{F}$ 点（図-8 (a), (b)）が準污染クラスター（両手法ともクラスター 6) に分類され，B，C，E点（図-8（a)，（b)）は手法 3 と 4 とは異なり污染の影響を受けていないクラス ターに分類された，以上のことから，手法 1 と 2 は 手法 3 と 4 より, 硝酸性窒素濃度による污染レベル との対応状況から適切に水質特性を表現していると 考えられる。

図-9に各クラスターのヘキサダイアグラムを示 す。クラスターの数を 5 とした場合と異なり，島原 市の水質特性をより適切に表現していると考えられ る手法 1 と 2 の間で各クラスターの各種イオンの濃 度を算術平均し，ヘキサダイアグラムを描画した。 なお, クラスター7は, 手法 1 では污染クラスター に, 手法 2 では準污染クラスターに属し, 特徴が異 なるため平均濃度は算出せず, 手法 1 については実 線で, 手法 2 については破線でへキサダイアグラム を描画した。污染の影響を受けていないクラスター 1 5 の水質組成は, クラスター 5 は $\mathrm{Na}^{-} \mathrm{HCO}_{3}$ 型, 他 は $\mathrm{Ca}^{-} \mathrm{HCO}_{3}$ 型を示す。準污染クラスターであるク 

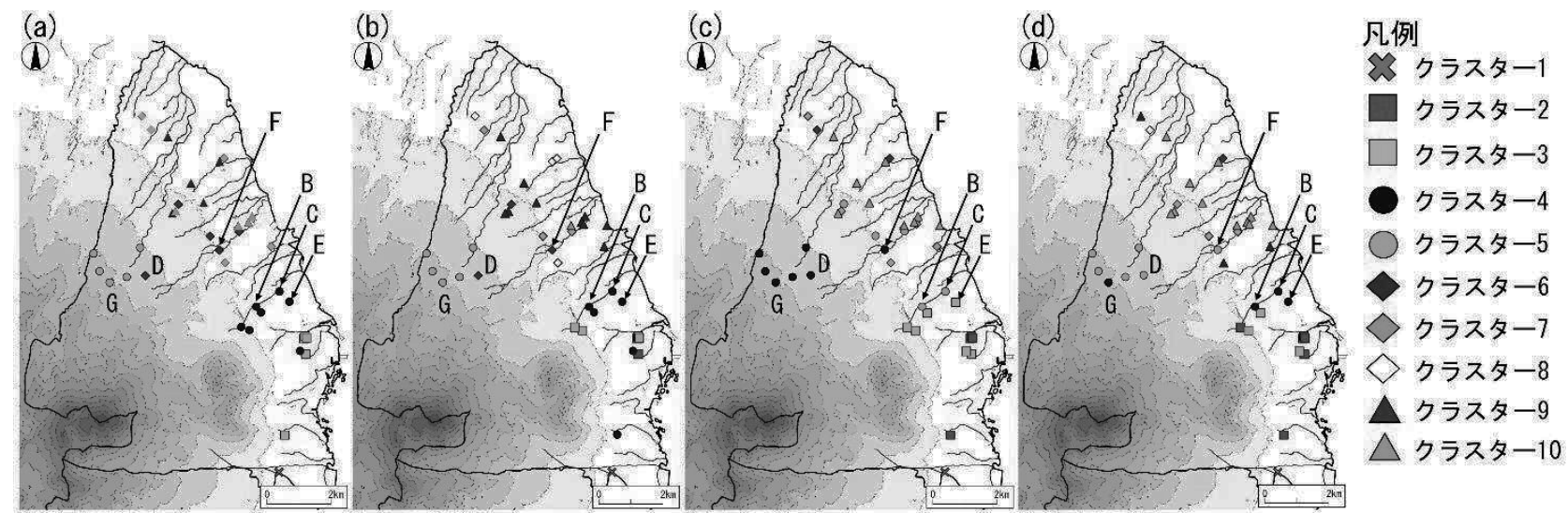

図-8 クラスターの数を 10 とした場合のクラスターの分布；（a）手法 1, （b）手法 2, (c) 手法 3, (d) 手法 4
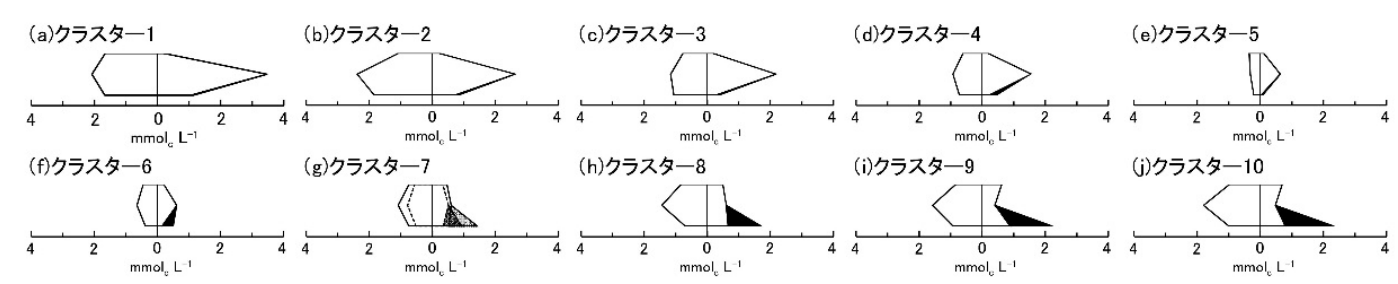

図-9 クラスターの数を 10 とした場合の各クラスターのヘキサダイアグラム

ラスター 6 の水質組成は, 污染の影響がへキサダイ アグラムからも確認できるものの $\mathrm{Ca}-\mathrm{HCO}_{3}$ 型を示 す.一方，污染クラスターであるクラスター8 10 は, $\mathrm{Ca}-\mathrm{NO}_{3}$ 型を示す，手法 1 では污染，手法 2 では 準污染クラスターに分類されるクラスター 7 は, 手 法 1 では $\mathrm{Ca}-\mathrm{NO}_{3}$ 型, 手法 2 では $\mathrm{Ca}-\mathrm{HCO}_{3}$ 型を示す. 市南部では, 標高が低くなるにつれて溶存イオン濃 度が上昇し, 水質組成は標高 $100 \mathrm{~m}$ 以下では $\mathrm{Ca}-\mathrm{HCO}_{3}$ 型である。市北部では, 標高が低くなるに つれて溶存イオン濃度が上昇するが，合わせて污染 の影響も受ける，水質組成は，標高 $200 \mathrm{~m}$ 以上では $\mathrm{Na}-\mathrm{HCO}_{3}$ 型, 標高 $100 \mathrm{~m}$ 付近では $\mathrm{Ca}^{-} \mathrm{HCO}_{3}$ 型, 標高 $100 \mathrm{~m}$ 以下では $\mathrm{Ca}^{-} \mathrm{NO}_{3}$ 型である.

\section{6. おわりに}

本研究では, 長崎県島原市を対象とし, 異なる4 つの多変量解析手法により水質分類を行った，解析 はクラスターの数を 5 または 10 とした場合の 2 通 りで実施し，それぞれの場合に扮いて分類結果を比 較した。 その結果, クラスターの数を 5 とした場合, 各クラスターの持つ意味はほぼ同様であり，いずれ の手法でも5つのクラスターは污染の影響をうけて いないクラスターと污染クラスターに分けることが できた，各クラスターの分布では，特定地点のクラ スター分類に違いが認められ, 硝酸性窒素濃度の分 布との比較から主成分分析を利用した手法 2 と 4 が
島原市の水質特性を説明するうえで適していると判 断された.

クラスターの数を 10 とした場合, 污染の影響を受 けていないクラスター, 污染クラスターそして準污 染クラスターに分けることができた。 クラスターの 数を増やしたため各クラスターの分布は, それぞれ の分類結果で異なっており, 硝酸性窒素濃度の分布 との比較から SOM を利用しない手法 1 と 2 が島原 市の水質特性を説明するうえで適していると判断さ れた。この結果は, 単一の事例にもとづくものなの で, 別のデー夕を用いて検討するなど, さらに検討 する必要がある。

以上のように，分類するクラスターの数を変えた 2 通りの場合において, 多变量解析の結果を比較し たところ，手法 2 が島原市の地下水水質を説明する に適する手法と判断された。研究対象地域の水質 デー夕は, 手法 1 のようにクラスター分析のみによ り分類することができるが, 分類されたクラスター の特徵と実際のデータの特徵が必ずしも一致しない ため, 本研究のようにいくつかの多変量解析手法を 試み, 対象地に適した解析手法を選択することが重 要であると考えられる.

本研究に扮いて手法 3 と 4 では, SOM 解析の後に クラスター分析するため, 入力データが手法 1 と 2 と比べ $1 / 3$ 程度となっている. 手法 1 と 2 では入力 デー夕数は同じであるが, 手法 2 に拈いて, パラメー 夕の数をイオン濃度の 8 個から主成分の数 2 個とし ている，つまり，デー夕数は減らさずに，パラメー 
夕数を減らすことが有効であったといえる。しか し, 手法 3 と 4 で用いた SOM 解析は, 図-4 や図-5 のように視覚的にデー夕間の関係性を表現すること が可能なため, 細かい分類精度だけでなく，目的に 応じた手法の選択も重要といえよう。

謝辞：本研究は, JSPS 科研費 24360194 および 15KT0120の助成を受けたものである。ここに記し て謝意を表す。

\section{参考文献}

1) Nadiri, A. A., Moghaddam, A. A., Tsai, F. T. C. and Fijani, E. : Hydrogeochemical analysis for Tasuj plain aquifer, Iran, Journal of Earth System Science, Vol. 122, No. 4, pp. 1091-1105, 2013.

2) Li, P., Qian, H., Wu, J., Zhang, Y. and Zhang, H. : Major ion chemistry of shallow groundwater in the Dongsheng coalfield, Ordos basin, China, Mine Water and the Environment, Vol. 32, No. 3, pp. 195-206, 2013.

3) Aiuppa, A., Bellomo, S., Brusca, L., D’Alessandro, W. and Federico, C. : Natural and anthropogenic factors affecting groundwater quality of an active volcano (Mt. Etna, Italy), Applied Geochemistry, Vol. 18, No. 6, pp. 863-882, 2003.

4) Matitaos, I. : Nitrate source identification in groundwater of multiple land-use areas by combining isotopes and multivariate statistical analysis: A case study of Asopos basin (Central Greece), Science of the Total Environment, Vol. 541, pp. 802-814, 2016.

5) Yidana, S. M., Ophori, D. and Banoeng-Yakubo, B. : A multivariate statistical analysis of surface water chemistry data - The Ankobra Basin, Ghana, Journal of Environmental Management, Vol. 86, No. 1, pp. 80-87, 2008.

6) 安元 純, 聖川健斗, 仲栄真史哉, 砥綿泰弘, 中野拓 治：多変量解析を用いた石灰岩帯水層に打ける地下水 水質の統計的分類, 土木学会論文集 B1 (水工学), Vol. 69, No.4, pp. I_595-I_600, 2013.

7) Cloutier, V., Lefebvre, R., Therrien, R. and Savard, M. M. : Multivariate statistical analysis of geochemical data as indicative of the hydrogeochemical evolution of groundwater in a sedimentary rock aquifer system, Journal of Hydrology, Vol. 353, No. 3-4, pp. 294-313, 2008.

8) Omonona, O. V., Onwuka, O. S. and Okogbue, C. O. : Characterization of groundwater quality in three settlement areas of Enugu metropolis, southern Nigeria, using multivariate analysis, Environmental Monitoring and Assessment, Vol. 186, No. 2, pp. 651-664, 2014.
9) Nguyen, T. T., Kawamura, A., Tong, T. T., Nakagawa, N., Amaguchi, H. and Gilbuena, R., Jr. : Clustering spatio-seasonal hydrogeochemical data using self-organizing maps for groundwater quality assessment in the Red River Delta, Vietnam, Journal of Hydrology, Vol. 522, pp. 661-673, 2015.

10) Jin, Y. H., Kawamura, A., Park, S. C., Nakagawa, N., Amaguchi, H. and Olsson, J. : Spatiotemporal classification of environmental monitoring data in the Yeongsan River basin, Korea, using self-organizing maps, Journal of Environmental Monitoring, Vol. 13, No. 10, pp. 2886-2894, 2011.

11）島原半島窒素負荷低減対策会議：第 2 期 島原半島窒 素負荷低減計画〜雲仙岳の恵みを次の世代に引き継 ぐために〜，長崎県環境政策課，100p，2011.

12）気象庁: 気象統計情報, http://www.jma.go.jp/jma/menu/ menureport.html（2016.04.01 閲覧）

13) Nakagawa, K., Amano, H., Asakura, H. and Berndtsson, R. : Spatial trends of nitrate pollution and groundwater chemistry in Shimabara, Nagasaki, Japan, Environmental Earth Sciences, Vol. 75, 234, 2016.

14）厚生労働省：水質基準項目と基準值, http://www.mhlw. go.jp/stf/seisakunitsuite/bunya/topics/bukyoku/kenkou/suid o/kijun/kijunchi.html（2016.06.01閲覧）

15）環境省：人の健康の保護に関する環境基準, http://ww w.env.go.jp/kijun/wt1.html（2016.06.01 閲覧）

16) Eckhardt, D. A. V. and Stackelberg, P. E. : Relation of ground ${ }^{-}$water quality to land use on long island, New York, Groundwater, Vol. 33, No. 6, pp. 1019-1033, 1995.

17) García, H. L. and González, I. M. : Self-organizing map and clustering for wastewater treatment monitoring, Engineering Applications of Artificial Intelligence, Vol. 17, No. 3, pp. 215-225, 2004.

18) Nakagawa, K., Amano, H., Kawamura, A. and Berndtsson, R. : Classification of groundwater chemistry in Shimabara, using self-organizing maps, Hydrology Research (2016. 06. 06 受理)

19) Kohonen, T. : The Self-Organizing Maps, Proceedings of The IEEE, Vol. 78, No. 9, pp. 1464-1480, 1990.

20）石原成幸, 河村 明, 天口英雄, 高崎忠勝, 高橋泰之, 川合将文：自己組織化マップを用いた東北地方太平洋 沖地震発生前後での東京の年間地下水変動特性, 土木 学会論文集 B1, Vol.70, No.4, pp.I_1129-I_1134, 2014.

(2016. 4.7 受付) 


\title{
CLASSIFICATION CHARACTERISTICS OF MULTIVARIATE ANALYSES FOR GROUNDWATER CHEMISTRY -CASE STUDY ON SHIMABARA CITY-
}

\author{
Hiroki AMANO, Kei NAKAGAWA and Akira KAWAMURA
}

Results of 4 multivariate analyses for groundwater chemistry were compared to discuss which classification result is the most suitable to explain water chemistry in Shimabara city. Though characteristics of 5 clusters are almost same among all multivariate analysis methods, the distributions of each cluster were different among 4 methods. In the two methods using row data of 8 major ion concentrations, higher nitrate concentration points were not classified into polluted clusters. In this regards, the two methods using principal component scores obtained by principal component analysis seem better to represent classification of the field water chemistry because both of points are belong to nitrate pollution cluster. When the number of cluster was determined to 10 , the method using principal component scores is more suitable than the other methods to explain water chemistry. 